International Journal of Business Management, Entrepreneurship and Innovation, Volume 3, Issue 3, 2021, PP 1-17, ISSN 2707-8027

IBMED

\title{
Dynamic Capabilities and Customer Satisfaction in Stock Investment Firms, Nairobi City County, Kenya
}

\author{
Hussein Mutiso Stanley ${ }^{1}$, Janesther Karugu ${ }^{2}$ \\ ${ }^{1}$ Student, Master of Business Administration (Strategic Management), School of Business of \\ Kenyatta University, Kenya \\ ${ }^{2}$ Department of Business Administration, School of Business, Kenyatta University, Kenya
}

ABSTRACT

An investment firm is expected to bring profit and benefits to the investors. If the investment firm remain to be true and to bring in consistent benefits that are risks free over time then the investors are confident to invest more financial assets in the firm. This means that the clients or customers are satisfied with the services of the firm. But in Kenya, there is a low level of customer satisfaction with the investment companies. The low level of customer satisfaction has grown tremendously in Kenya. This has affected the firms and the economic growth of Kenya, for investment firms is a strong backbone of Kenyan economic growth. Dynamics capabilities are expected to improve customer satisfaction. On this background this study endeavored to establish the influence of dynamic capabilities on customer satisfaction of Investment Firms in Kenya. The specific objectives of the study were to establish the effect of learning capabilities, integration capabilities, innovation capabilities and strategic alliances on customer satisfaction. The study utilized an explanatory research design to determine how the identified dynamic capabilities affect customer satisfaction in investment firms in Nairobi city county, Kenya. The study was explained by the theory of dynamic capabilities and resource-based view. The target population in the study included 135 investment firms that are registered under Nairobi Security Exchange. Stratified random sampling and purposive sampling were used to select the sample size of 56 investment firms from the target population and 168 target respondents respectively. This research employed both primary and secondary data. Primary data was gathered with the help of semi-structured questionnaires. These included both closed and open-ended questions. This study used both quantitative and qualitative methods. Quantitative data was analyzed by use of both descriptive and inferential statistics by use of statistical package for social sciences (SPSS version 22). The study findings showed that learning capabilities, integration capabilities, innovation capabilities and strategic alliances have a positive and significant influence on customer satisfaction. It was concluded that encouraging participative decision making between among all staff leads to improved customer satisfaction. It was also concluded that having open forums during which staff share ideas is important as it enhances customer satisfaction. Moreover, it was concluded that having both the senior and subordinate staff involved in setting organizational goals leads to customer satisfaction. It was further concluded that having all stakeholders are invited on board to take part in strategic planning improves customer loyalty. The study recommended that Investment firm's management should encourage participative decision making between among all staff to enhance customer loyalty. It was further recommended that firms should implement open forums during which staff share ideas to enhance customer satisfaction. The management should be aggressive in revision of firm goals and activities.

Key Words: Dynamic Capabilities, Customer Satisfaction, Innovation, Strategic Alliances

DOI 10.35942/jbmed.v3i3.203 
International Journal of Business Management, Entrepreneurship and Innovation, Volume 3, Issue 3, 2021, PP 1-17, ISSN 2707-8027

BED

\section{Cite this Article:}

Mutiso, H., \& Karugu, J. (2021). Dynamic Capabilities and Customer Satisfaction in Stock Investment Firms, Nairobi City County, Kenya. International Journal of Business Management, Entrepreneurship and Innovation, 3(3), 1-17. https://doi.org/10.35942/jbmed.v3i3.203

\subsection{Introduction}

Dynamic capabilities are defined as the abilities of a company to adopt, integrate and build on competencies in order to cope with the changing environment to remain relevant in the market (Teece, 2007). Both the use and usefulness of dynamic capabilities increase in turbulent environments characterized by intense competition, rapid technological progress, and frequent changes in customer preferences than in stable environments (Pavlou and El Sawy, 2011; Teece, 2007). This study focused on dynamic capabilities such as; learning capabilities, integration capabilities, innovation capabilities and strategic alliances which have been established to be effective constructs of dynamic capabilities in the past (Kuria, 2015; Mukhobe, 2015; Mutai, 2017). In a competitively dynamic market, the firm's retention of its customers can be vital to success. Enhancing customer-perceived quality (a measure of satisfaction) benefits a firm to a great extent. Fornell, Mithas, Morgeson and Krishnan (2006) found a notable connection between customer satisfaction, firm performance, and risk: their research showed that satisfied customers are economic assets with high returns and low risk. Dynamic capabilities by Teece, Pisano and Shuen (1997) support the fact that a firm can build on skills and accumulate knowledge that enable firms to coordinate activities, make use of their assets to give their customers quality goods and services. The resource-based view (RBV) was used as a theoretical background to study the manner in which investment firm's resources and capabilities influences the customer satisfaction of a firm (Wernefelt, 1984). Kenya stands as a very competitive investment market and thus a need for the investment firms to respond to the dynamism in the market by formulating capabilities and strategies that involve learning, adopting, absorption of knowledge and creating new products that are up to date with an end goal of building a competitive advantage. Investment firms in Kenya operate in a fast-moving business environments open to global competition and characterized by dispersion in the geographical and organizational sources of innovation and manufacturing, sustainable advantage requires more than the ownership of difficult to replicate (knowledge) assets and win the confidence of customers (Park \& Kang, 2013).

Customer satisfaction refers to an attitude expressed by a customer as a response to how much fulfillment is obtained after buying a good or after receiving a service. Customer satisfaction is the customer's perception that a vendor has met the expectations fully efficiently and promptly (Sugandhi, 2008). On the basis that customers expect quality and the best, investment firms should endeavor to ensure that they satisfy their customers' expectations. This is because out of every service or goods the customers receive it is expected that they have to give their opinions about the product after they have used it, this means that the testimonials from the customers of investment companies are essential for a firm's growth and success. Customers' testimonials are the best advertising modes a firm can ever use. Several tools have been used in the past to measure customer satisfaction, these are; tracking and measuring customer satisfaction: complaint and suggestion systems, customer satisfaction surveys, ghost shopping and lost customer analysis (Gichuru, 2011). It has been found that more than $90 \%$ of dissatisfied customers will not exert their own effort to contact a company to complain; they will simply take their business to a 
International Journal of Business Management, Entrepreneurship and Innovation, Volume 3, Issue 3, 2021, PP 1-17, ISSN 2707-8027

IBNED

competitor while voicing their dissatisfaction to other potential customers. Customer satisfaction programs are important tools that can increase profits by preventing customers from defecting. Losing one dissatisfied customer may be more severe than it sounds; one dissatisfied customer may speak to as many as nine others, multiplying the dissatisfaction nine-fold (Gichuru, 2011). The importance of effective complaint management system, service recovery, customer delight cannot be understated.

In United States, the American Customer Satisfaction Index (ACSI) is an economic indicator that measures the satisfaction of consumers across the U.S. economy. The ACSI interviews about 350,000 customers annually and asks about their satisfaction with the goods and services they have purchased and consumed. Respondents are screened to ensure inclusion of actual customers of a wide range of business-to-consumer products and services, including durable goods, services, nondurable goods, local government services, federal government services, and so forth. Customer satisfaction (ACSI) scores are released monthly throughout each calendar year. ACSI data is used by researchers, corporations, government agencies, market analysts and investors, industry trade associations, and consumers (Obunwo, 2016). In African Countries, Belás and Gabčová, (2016) mention quality of the core services and quality of the relationships as the main dimensions affecting customer satisfaction. According to the authors, quality of core services includes reliability, security, functionality, accuracy, and speed while quality of relationships includes responsiveness, competences, assurance, trust, friendliness, courtesy, availability, commitment, flexibility, and communication. In addition, satisfaction is key in enabling organizations to assess their relationships with customers (Keisidou, Sarigiannidis \& Thalassinos, 2018). These relationships are important sources for improved performance in organizations because they help to reduce costs, increase quality, improve products and services, bring in useful knowledge that assist in product innovation and create long-term customer loyalty.

In Kenya, it is a common phenomenon that the services a brand offers and the price it charges actually determine the level of satisfaction among its customers, than any other measure (Turel et $a l, 2006)$. Customer's involvement is also important as when buyer consider the product important and invests time to seek information then it ultimately enhances the satisfaction level (RussellBennett, McCoil-Kennedy \& Coote, 2007). This satisfaction may influence the concerned company by repurchase, purchase of more products, positive word of mouth and willingness of customer to pay more for the particular brand. Any business is likely to lose market share, customers and investors if it fails to satisfy customers as effectively and efficiently as its competitors is doing (Anderson, Forneil \& Mazvancheryl, 2004). Customer satisfaction is the most important factor that affects customer loyalty (Hoq et al., 2010). It is an important theoretical as well as practical issue for most marketers and consumer researchers (Jamal et al., 2003) if customer is satisfied, a likelihood for return is possible.

Investment firm is a financial oriented institution oriented to engage in investing in securities (Karimi, 2013). An investment decision involves a choice on how to commit funds now in anticipation of expected flow of benefits in the future. It is an exchange of current funds for future benefits. The investment firms contribute to the economic growth of Kenya. Every firm operates strictly on the basis of the license given to it. Even though investment firms have been increasing over time there is a challenge in the volume of funds supplied in comparison to other securities, this brings about many questions about the knowhow of the handling of funds, and investor confidence and knowledge of the different investment vehicles available (Karimi, 2013). In Kenya, there are various investment firms, which are established and licensed by the Capital Markets 
International Journal of Business Management, Entrepreneurship and Innovation, Volume 3, Issue 3, 2021, PP 1-17, ISSN 2707-8027

IBNED

Authority (CMA). Some of the NSE (Nairobi Stock Exchange) listed investment firms in Kenya are; Olympia capital holdings, City Trust, Trans Century and Centum Investments (Karimi, 2013). However, there are many other investment firms. These firms engage local participants in their equity, thereby opening doors for Kenyan citizens to own shares. They are companies that can raise extra money for development and growth, the raising of funds is done by the issuer drafting a prospectus, it is an outline that showcases the operations to be carried, the upcoming prospects and specifies the state of the issue (Kanyuru, 2010). It is generally accepted that investment firms declaring stock distributions of 25 per cent or greater consider them as stock splits which, therefore, have no effect on retained earnings. Stock distributions of less than 25 per cent are considered as stock dividends that reduce the retained earnings account (Owolabi and Inyang, 2013).

\subsection{Statement of the Problem}

An investment firm is expected to bring profit and benefits to the investors. If the investment firm remain to be true and to bring in consistent benefits that are risks free over time then the investors are confident to invest more financial assets in the firm (Barber,Lehavy \&Trueman 2017). This means that the clients or customers are satisfied with the services of the firm. But in Kenya, there is a low customer satisfaction with the investment companies. The low customer satisfaction has grown tremendously in Kenya. This has affected the firms and also the economic growth of Kenya, for investment firms is a strong backbone of Kenyan economic growth (Kariuki, 2019). For instance, recently the complaints of Ekeza investment group customers, has contributed to the decreasing customer satisfaction towards investment firms. According to Kariuki (2019) the firm opened up a window for Kenyans to invest their money to help the firm run the business and in return reap a two per cent monthly interest. Today, the firm is accused of siphoning more than Sh1 billion belonging to 78,000 members; these customers have lost trust with the company. This case has made Ekeza investment group to lose its market share, the incidence have also jeopardized the existing reputation of investments companies in Kenya. Dynamic capabilities are expected to improve the customer satisfaction to a great extent and save the investment groups in Kenya from losing their customer base.

Several studies have been done in Kenya on the issue of dynamic capabilities but most of these studies have concentrated on different industries like insurance, shipping and banking institutions leaving out the industry of investment firms. A study by Kuria (2015) focused on dynamic capability and competitiveness of Safaricom Limited in Kenya, this study poses a conceptual gap, whereby it focused on competitiveness rather than customer satisfaction which the current study seeks to concentrate on. Similarly, Mukhobe (2015) concentrated on the role of dynamic capability on performance of shipping industry, in his study he did not focus on customer satisfaction in investment firms, leaving a conceptual gap which the current study seeks to fill. Further, Mutai (2017) on the effect of dynamic capabilities on organizational competitiveness, he concentrated on a case of Uber Taxi Kenya and failed to address the satisfaction received by customers from investment firms in Kenya.

\subsection{Research objectives}

The main objective of this study was to establish the influence of dynamic capabilities on customer satisfaction in stock investment firms, Nairobi city county, Kenya.

This study was guided by the following specific objectives: 
International Journal of Business Management, Entrepreneurship and Innovation, Volume 3, Issue 3, 2021, PP 1-17, ISSN 2707-8027

IBMED

i. To establish the influence of learning capability on customer satisfaction in stock Investment Firms in Kenya.

ii. To determine the effect of integration capability on customer satisfaction in stock Investment Firms in Kenya

iii. To assess the influence of innovation capability on customer satisfaction in stock Investment Firms in Kenya

iv. To determine the effect of strategic alliances on customer satisfaction in stock Investment Firms in Kenya

\subsection{Literature Review}

\subsection{Theoretical Literature Review}

This section explains some of the concepts that explain the association between specific variables of dynamic capabilities and customer satisfaction. The theory discussed here explains dynamic capabilities. The theory is known as dynamic capability theory.

\subsubsection{The theory of Dynamic Capabilities}

This theory was developed Teece, Pisano and by Shuen (1997). Dynamic capability is the as firm's capacity to assimilate, build and reconfigure internal and external competencies to counter the consistently changing environment. Dynamic capability by distinction is the ability of any organization to firmly make, spread or alter its resource base (Helfat et al., 2007). Dynamic capability therefore postulates that core competencies should be used to adjust short term competencies to build long term competitive advantage for the organization. Teece's notion of dynamic capability fundamentally saw corporate agility as paramount for survival of any business. For instance, organizations must be able to understand opportunities and threats to seize the opportunities whilst maintaining competence through enhancing, merging, shielding and if required reconfiguring the organization's tangible and intangible assets. The prerequisite of learning is shared codes of communication and synchronized search procedures. The organizational knowledge produced exists in new patterns of action, in routines or a new logic of organization.

Dynamic capability theory focuses on how organizations can uphold threshold capability to guarantee competitive performance and how senior management of such organizations can shift their present mental paradigms to adapt to essential discontinuous change. The theory attempts to explain how new capabilities can be developed and how novel resource and capability combinations help to attain or sustain competitive advantage under conditions of technological and market changes (Teece, 2009). Every business needs to possess a certain level of strategic firm capability in order to survive and thrive in a competitive business environment. The type of strategic capability that the company needs at a specific time is determined by the legitimizing forces and the threats or opportunities in the future business environment (Armstrong \& Greene, 2007). This framework was useful in this study as it provided an answer to the fundamental question as to why some investment firms experience greater customer satisfaction while others fail. This theory was adopted in this study as it analyzes internal and external resources and competences toward the changing environment so as to respond to customer requirements. This theory was relevant to the specific objectives of the study which are to: establish the influence of learning capability on customer satisfaction of Investment Firms in Kenya, determine the effect of integration capability on customer satisfaction of Investment Firms in Kenya, assess the influence 
International Journal of Business Management, Entrepreneurship and Innovation, Volume 3, Issue 3, 2021, PP 1-17, ISSN 2707-8027

IBNED

of innovation capability on customer satisfaction of Investment Firms in Kenya and to determine the effect of strategic alliances on customer satisfaction of Investment Firms in Kenya.

\subsubsection{Resource Based View}

Wernerfelt (1995) describes Resource Based View theory as a method of achieving competitive advantage. The proponents of RBV argue that the sources of competitive advantage of an organization lies within the organization itself and not in its competitive environment. In addition, they make claim that the sustainable competitive advantage of a firm is dependent on the capability it has to manage the institutional context of its resource decisions. The resource based view of the firm provides a conceptually grounded framework for assessing strengths and weaknesses and enables strengths or weakness to be examined in terms of criteria for establishing sustainable competitive advantage. Resources are inputs into a firm's production process, such as capital, equipment, skills of individual employees, patents, finance and talented managers. Resources are either tangible or intangible in nature. Individual resources may not yield to competitive advantage. It is through synergistic combination and integration of sets of resources that competitive advantage is formed. Barney (1991) states that the following are the key characteristic of a resource to be strategically important: Valuable; for there is no point having a resource if it does not deliver value to the firm. Rare, because resources that are owned by a large number of firms cannot offer competitive advantage as they cannot deliver a unique strategy. Inimitable reason being that resources can only be a source of sustained competitive advantage if firms that do not possess these resources cannot obtain them. Lastly they must be non-substitutable this means that other organizations cannot make a look alike of the resource.

According to Coates and McDermott (2002), the resource based view of strategy emphasizes that a firm utilizes its resources and capabilities to create competitive advantage that ultimately results in superior value creation. The firm's resources and capabilities together form distinctive competences. These competences enable innovation, efficiency, quality and customer responsiveness, all of which can be leveraged to create a cost advantage or a differentiation advantage (Scholes \& Johnsone, 2001). According to Chaharbaghi and Lynch (1999) the existing resources of a firm may not be adequate to facilitate the future market requirements, due to the volatility of the contemporary markets. There is vital need therefore to modify and develop resources in order to encounter the future market competition. An organization should exploit existing business opportunities using the present resources while generating and developing a new set of resources to sustain its competitiveness in the future market environments; hence, an organization should be engaged in resources management and resource development. This theory shows that through resources such as organizational learning, integration of services and innovation in an organization, improved service delivery and subsequent customer satisfaction may be observed. This is because it enhances employee engagement in an organization as they are able to understand the mission and vision and also comprehend their roles in the organization.

\subsection{Empirical Literature Review}

There are a number of studies that have been conducted in the past to show the association between dynamic capabilities and customer satisfaction. Therefore, this study reviews past studies to the effect of learning capability, integration capability, innovation capability and strategic alliances. Hailekiros and Renyong (2016) studied the effect of learning capability on a firm performance. Survey data of 243 small and medium sized manufacturing companies was used. The study was carried out in Ethiopia. A questionnaire was used as the data collection tool. Cross sectional data 
International Journal of Business Management, Entrepreneurship and Innovation, Volume 3, Issue 3, 2021, PP 1-17, ISSN 2707-8027

\section{IBMED}

was used in the study. SME and PCA approaches were used to test for the relationship that existed between the study variables. Learning capability was found to have a strong and positive effect on firm performance. The study mainly focused on the manufacturing industry and therefore generalizing the results to other industries would not be the right inference. Therefore, the current study focused on investment firms to fill the gap.

Onağ, Tepeci and Başalp (2014) conducted an investigation on the levels and dimensions of learning capabilities on the performance of firms. The target respondents of the study were entry and middle level managers of firms. They totaled up to 143 managers. Survey approach was used where web and personal visits were the ways used to conduct the survey. Learning capability was found to be in seven dimensions: dialogue, participative decision making, experience, knowledge transfer, experience and openness, and managerial commitment. These learning capabilities were found to influence organizational innovativeness. The investigation mainly focused on innovativeness as the dependent variable but failed to look at customer satisfaction. Akgün, Keskin, Byrne and Aren (2007) conducted a study on emotional and learning capability and their effect on innovativeness and firm performance. The study used 106 firms as the target population of the study. Multi-item constructs scales were used for the measurement of scales. Emotional capability was found to have an effect on learning capability. The learning capability constructs were managerial commitment, openness and experimentation, and knowledge transfer and integration and system perspective. In conclusion, learning capability affected by emotional capability had a positive effect on firm's performance.

Onyando (2018) studied the effect of integration capability as an independent variable on the performance of manufacturing firms in Nairobi. Resource based view theory was used as an informative theory in the study. Cross sectional survey was conducted where explanatory research design was employed to make it possible. The target population was 369 from which 271 firms were selected as the sample size of the study. Factor analysis was used for validity purposes. Moderated multiple regression was used to analysis the relationship between the variables under study. The study found out that reconfiguration capabilities also known as integration capabilities had a significant effect on the performance of the firm. It was also showed that the interaction of transactional leadership with integration capabilities had a meaningful effect on the performance of the firm. The study concluded that integration capability had a tangible effect on firm performance and the leadership in use informed the relationship between the two, that is, integration capabilities and firm performance. Pedron, Picoto, Colaco, and Araújo (2018) explored on dynamic capabilities theory with an aim of formulating a model that would bring a better understanding of the innovation capabilities. One of the variable under the study was integration capabilities. The study used exploratory research design. Expert oriented interviews were employed to obtain qualitative data. The study found out that integration capabilities enabled better customer relationship management which in turn generated innovation. Integration capabilities were in form of reconfiguring market opportunities and hazards. The study recommended organizations to embrace reconfiguration practices as a way of enhancing innovation and thus creating better and sustainable competitive advantage. The study focused on the formulation of model but failed to concentrate on specific dynamic capabilities variables that affect customer satisfaction, which was the focus of the current study. Wogwu and Hamilton (2018) investigated the effect of integration capabilities on competitive advantage. This was done in the public sector in Nigeria. Reconfiguration capability is the ability of an organization to rebuild assets and also gain knowledge for creativity that will enable it utilize opportunities and survive threats. 
International Journal of Business Management, Entrepreneurship and Innovation, Volume 3, Issue 3, 2021, PP 1-17, ISSN 2707-8027

\section{IBMED}

Knowledge based theory and porter's five forces were used as the underpinning theories of the study. The need for utilizing and enlarging the essential element of reconfiguration capabilities was emphasized. The study recommended that the government of Nigeria ought to go for a restructuring approach in order to strengthen the public health sector. The study found out a positive and a significant association between integration capabilities and competitive advantage of the public sector. However, the study did not explain the integration elements that needed to be enlarged. Further, the study focused on the health sector rather than investment firms which this study focused on.

Peace and Sylva (2017) studied the association between service innovativeness and customer satisfaction of four star hotels in River state. A list of 12 hotels were used as the target population. The study used a one snap shot method of data collection. A relationship between service innovation and customer satisfaction is strong. This study concluded that the dimensions of service innovation used in the four star hotels were effective in service delivery and service outcome which proved as an effective marketing tool satisfying many customers. The study had a limitation of time, in that, the results were obtained from a snapshot observation but not a long time observation. Kiey and Bayoh (2017) conducted a study on the relationship between innovation and customer retention. The study was conducted in the telecommunication industry in Ghanaian industry. Quantitative research approach was employed in the study. The target respondents used were 365 mobile phone users. Due to the difficult of obtaining a sample frame of all the mobile users' convenience sampling was used. Self-administered questionnaires were used to collect data. Descriptive statistics and multiple regression were used to establish the relationship between the independent variables and the dependent variable. The study found out a positive and a significant relationship between innovation and customer retention. Service innovation was found to be a chief determinant of customer satisfaction. A recommendation was given to the companies to consider the employment of service innovation, process innovation and marketing innovation. A study by Diaw and Asare (2018) investigated the effect of innovation on customer satisfaction in the telecommunication industry in Ghanian. The study used 150 customers of companies such as, Vodafone, MTN, Tigo-Airtel, Expresso and Glo. Data analysis was employed to reveal the relationship that existed between predictor variables and outcome variable. The study found out a significant relationship between innovation and customer satisfaction. The study recommended the telecommunication companies to invest heavily in innovation because it would help in forecasting products and services.

Kimani (2014) investigated the effect of strategic alliances on competitive advantage at Airtel Kenya limited. Case study design was used. This design enabled an in depth study on strategic alliances and an efficient exploration on the competitive advantage of the company. The study used primary data obtained from seven managers who were involved in the formation of strategic alliances in the company. In addition, secondary data from newspaper, articles, journals, magazines and reports was also used. Content analysis was used to handle the qualitative data that was gathered. This data was important in gathering the different views of the respondents, on the issues they agreed and disagreed. Airtel Kenya was found to have alliances with several parties such as banks, internet providers, mobile phone makers and health insurance firms with a goal of growing their customer base, revenue and promote their brand. From the findings, the study revealed that the strategic alliances had given yield to better customer satisfaction, added customer value, transfer of new technologies, and reduction in operational costs. The study recommended Airtel Kenya to continue partnering with other parties since the alliance would create more market 
International Journal of Business Management, Entrepreneurship and Innovation, Volume 3, Issue 3, 2021, PP 1-17, ISSN 2707-8027

\section{IBMED}

share for the company and also impact positively the lives of people and as a result improve its image. This study by Kimani (2014) proved that there was a positive and significant association between strategic alliances and customer satisfaction. However, this study focused on one company as an investment firm, while this study focused on several investing firms in Kenya.

Mwangi (2014) studied the influence of strategic alliances at Kenya Commercial Bank Group. The study used a case study design. Both primary data and secondary data were used. Interview guides were used to gather primary data. The study found out that strategies were providing a platform for the bank to tap resources, skills, abilities and knowledge from the other parties. Further, strategic alliances were found to offer an opportunity for the bank to leverage its resource capabilities. The relationship between strategic alliances and bank competitiveness was found to be positive and significant. Bank competitiveness was looked into in terms of increasing the sales, profitability and increasing the customer base. The investigation recommended that the inclusion of competitive intelligence by commercial bank when it comes to application of strategic alliances. Technological intelligence was cited as one form of intelligence that would bring about huge benefits in terms of automation, cost reduction and efficient service delivery. The study showed that the relationship between strategic alliances and performance of commercial banks was positive. However, this study failed to give attention on the level of customer satisfaction.

Wandia and Ismail (2019) conducted a study on influence of strategic alliances on the performance of commercial banks. They solely focused on Kenya commercial Bank. Some of the variables that were under study were; synergy, strategic orientation, and the firm commitment. Theories that guided the study are; trust based rationalism, transaction cost economics, information processing theory and multilevel theorizing. The target population was 486 members of staff in different managerial positions at Kenya commercial bank. Stratified random sampling was used to select a sample of 219 members. Questionnaires were utilized as the data collection tool. Pilot study was also used to do pre-test and ensure the validity of the questionnaires. Content analysis was applied for analyzing qualitative data collected through the use of open ended questionnaires. Multiple regression analysis was also used. Partner match was found to positively affect the performance of different the commercial bank. However, even though partner alliances were found to bear positive fruits in terms of the bank performance. The study recommended the Kenya commercial bank to be keen in choosing strategic partners. By doing, conflicts will be avoided between parties because carefully sought partners will enable the creation of a win win partnership thereby creating a strong synergy. The study informs the current study, however it failed to sharply focus on the effect of strategic alliance on customer satisfaction and not only for one commercial bank but generally for all the investment firms.

\subsection{Conceptual Framework}

A conceptual framework is a diagrammatical representation of research variables under investigation (Mugenda \& Mugenda, 2003). This framework enabled the researcher to identify with the issues being measured. It shows the relationship that exist between the independent variables and the dependent variable. In this study, the independent variables were; learning capabilities, integration capabilities, innovation capabilities and strategic alliances capabilities. The dependent variable was customer satisfaction.

In this study the independent variables were learning capabilities, integration capabilities, innovation capabilities and strategic alliances. The dependent variable was customer satisfaction. Learning capabilities was measured through knowledge transfer, experience and participative 
International Journal of Business Management, Entrepreneurship and Innovation, Volume 3, Issue 3, 2021, PP 1-17, ISSN 2707-8027

\section{BED}

decision making. The indicators of integration capabilities were reconfiguring market opportunities and frequency of revision of activities. The innovation capabilities variable was assessed through market innovation, process innovation and product innovation. On the other hand, strategic alliances indicators were shared expertise, shared knowledge and shared knowledge. The dependent variable which was customer satisfaction was measured through cooperation, communication and public image.

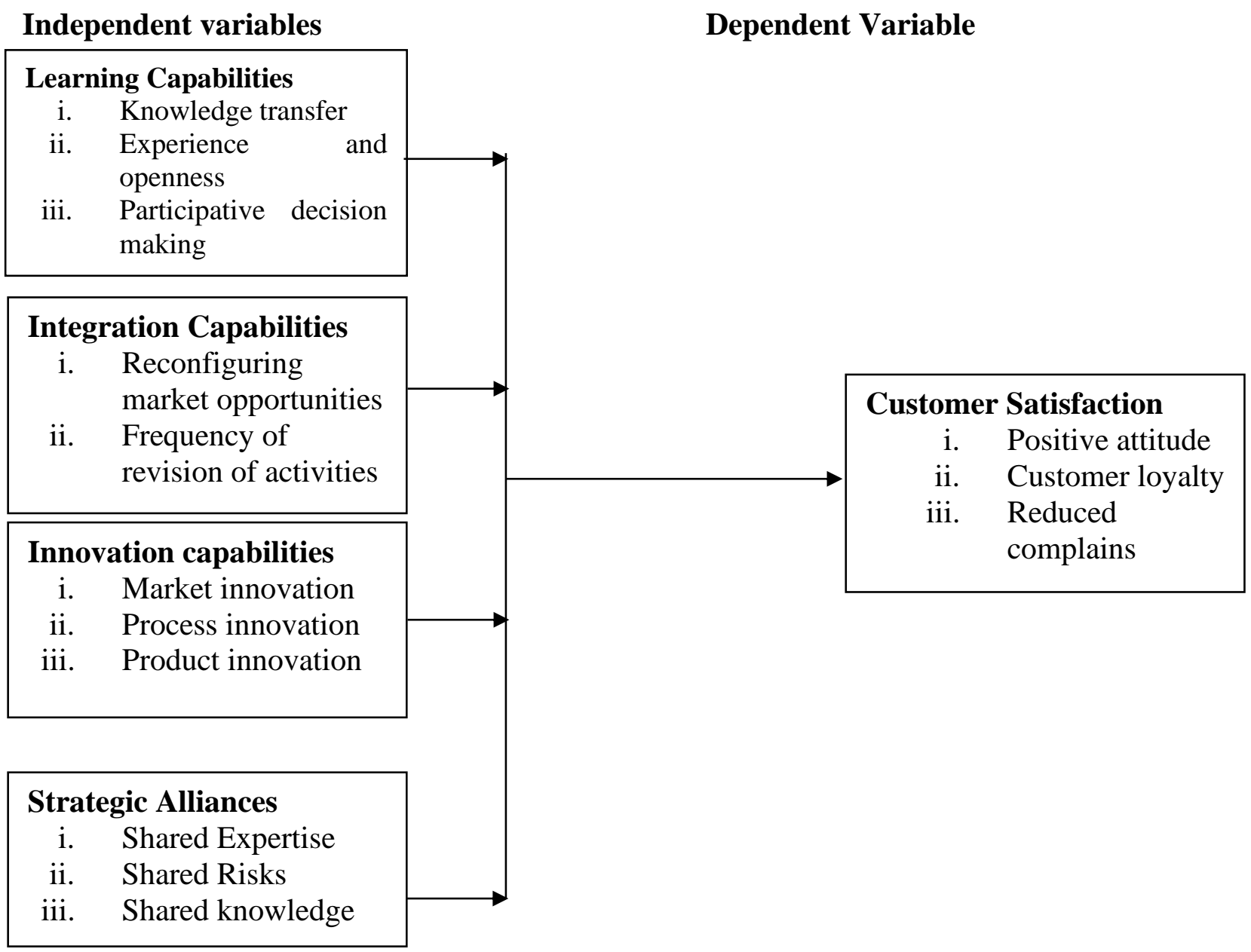

Figure 1: Conceptual framework

Source: Researcher, 2021

\subsection{Research Methods}

The study used explanatory research design. The justification for this design is that it helps the researcher to find out what is happening and enables the search of new ideas and insights (Robson, 2002). This kind of research is employed on a topic which has not been clearly examined. It is also conducted on a topic that needs to establish priorities, establish clear operational definitions and advance the final design of the research. This research therefore employed explanatory research design to look deeper into how the identified dynamic capabilities affect customer satisfaction in investment firms in Nairobi city county, Kenya. The target population included 135 investment firms that are registered by the Nairobi Security Exchange as of 2018 (NSE, 2018). These investment firms were then classified into three groups based on their market share, that is; 
International Journal of Business Management, Entrepreneurship and Innovation, Volume 3, Issue 3, 2021, PP 1-17, ISSN 2707-8027

IBMED

major companies whose market share is above $4 \%$, medium sized companies whose market share is between $1 \%$ and $4 \%$ and small companies whose individual market share is less than $1 \%$. The research findings reflect how the dynamic capabilities affect the customer satisfaction of the investment firms in Nairobi city county. All the 135 targeted investment firms have a representative office in Nairobi which made it easy to access them. Therefore, the study included visiting all the firm's offices around Nairobi city county for data collection.

Since the population was less than 10,000, the fisher et al, (2003) formula was employed. Therefore, the sample size was 56 investment firms that were registered by the Nairobi Securities Exchange 2018 report. Stratified random sampling was used to select the investment firms to be included in the study. The strata were formed by the size of the firms; small firms, medium firms and large firms. Purposive sampling was then used to select three respondents from each investment firm to participate in the study. Primary data was gathered with the help of structured questionnaires. The closed ended questions were employed in standardizing answers while saving the amount of time used to fill in the questionnaires. It helped in gathering the quantitative data. This approach helped in gathering qualitative data that was useful to describe what is happening and provide a measure of respondents' opinions, attitudes, feelings, and perceptions regarding the topic under investigation. The research also made use of the 5-point likert scale in finding out the connection between dynamic capabilities employed by the investment firms and their level of customer satisfaction. This study used both quantitative methods. Quantitative data was analyzed by use of both descriptive and inferential statistics by use of statistical package for social sciences (SPSS version 22). Descriptive statistics included measures of central tendencies (mean) and measures of dispersion (standard deviation). The data was then presented in tables and graphs. Inferential statistics such as correlation analysis and multivariate regression analysis were used to establish whether there is a relationship between the dependent and the independent variables.

\subsection{Research Findings}

\subsection{Learning Capability and Customer Satisfaction}

The study aimed at assessing the influence of learning capability on customer satisfaction in stock investment firms. Correlation analysis was conducted to find out the link that exist between learning capability and customer satisfaction. The findings showed that there was a positive and significant link between learning capability and customer satisfaction $(r=0.716, p=0.013)$. This implies that an increase in learning capability would lead to improved customer satisfaction. The result agrees with Hailekiros and Renyong (2016) who found a strong and positive effect of learning capability on firm performance. The results in table below presents the fitness of model of regression model used in explaining the influence of learning capability on customer satisfaction.

Table 1 Regression Model for Influence of influence of learning capability on customer satisfaction

\begin{tabular}{|c|c|c|c|c|c|}
\hline Model & $\mathbf{R}$ & R Square & Adjusted R Square & \multicolumn{2}{|c|}{$\begin{array}{l}\text { Std. Error of the } \\
\text { Estimate }\end{array}$} \\
\hline 1 & .716 & .512 & .503 & \multicolumn{2}{|c|}{.53823} \\
\hline Model & & $\begin{array}{l}\text { Sum of } \\
\text { Squares }\end{array}$ & Mean Square & $\mathbf{F}$ & Sig. \\
\hline 1 & Regression & 27.01 & 27.01 & 126.98 & 0.000 \\
\hline 1 & Residual & 9.92 & 0.315 & & \\
\hline
\end{tabular}


International Journal of Business Management, Entrepreneurship and Innovation, Volume 3, Issue 3, 2021, PP 1-17, ISSN 2707-8027

IBMED

Total $\quad 36.93 \quad 126$

\begin{tabular}{lcccc} 
& $\boldsymbol{\beta}$ & Std. Error & $\mathbf{t}$ & Sig. \\
(Constant) & 1.876 & 0.201 & 9.369 & 0.000 \\
learning capability & 0.521 & 0.053 & 9.83 & 0.001 \\
\hline
\end{tabular}

Learning capability was found to be satisfactory variable in explaining customer satisfaction. This was supported by coefficient of determination also known as the R square of $51.2 \%$. This meant that learning capability explain $51.2 \%$ of the variations in customer satisfaction. The results further meant that the model applied to link the relationship of the variables was satisfactory. The outcomes of ANOVA showed that the final model was statistically significant. Further, the results inferred that learning capability was a good predictor of customer satisfaction. This was confirmed by the F statistic of 126.98 and the recorded $p$ value (0.000) that was smaller than the traditional likelihood of 0.05 significance level. Regression of coefficients results in revealed that learning capability has a positive and significant influence on customer satisfaction $(\beta=0.521, p=0.001)$. This means that a unit change in learning capability would lead to a change in growth of nonperforming loans by 0.521 units. The finding is in line with that of Akgün, Keskin, Byrne and Aren (2007) who study found that learning capability affected by emotional capability had a positive effect on firm's performance.

\subsection{Influence of integration capability on customer satisfaction}

The study aimed at assessing the influence of integration capability on customer satisfaction. Correlation analysis was conducted to find out the link that exist between integration capability and customer satisfaction. The findings showed that there was a positive and significant relationship between integration capability and customer satisfaction $(r=0.707, p=0.011)$. This implies that an increase in integration capability growth would lead to more customer satisfaction. This finding is in line with that of Onyando (2018) who found that integration capability had a tangible effect on firm performance.

Table 2 Model summary for Influence of Integration Capability on Customer Satisfaction

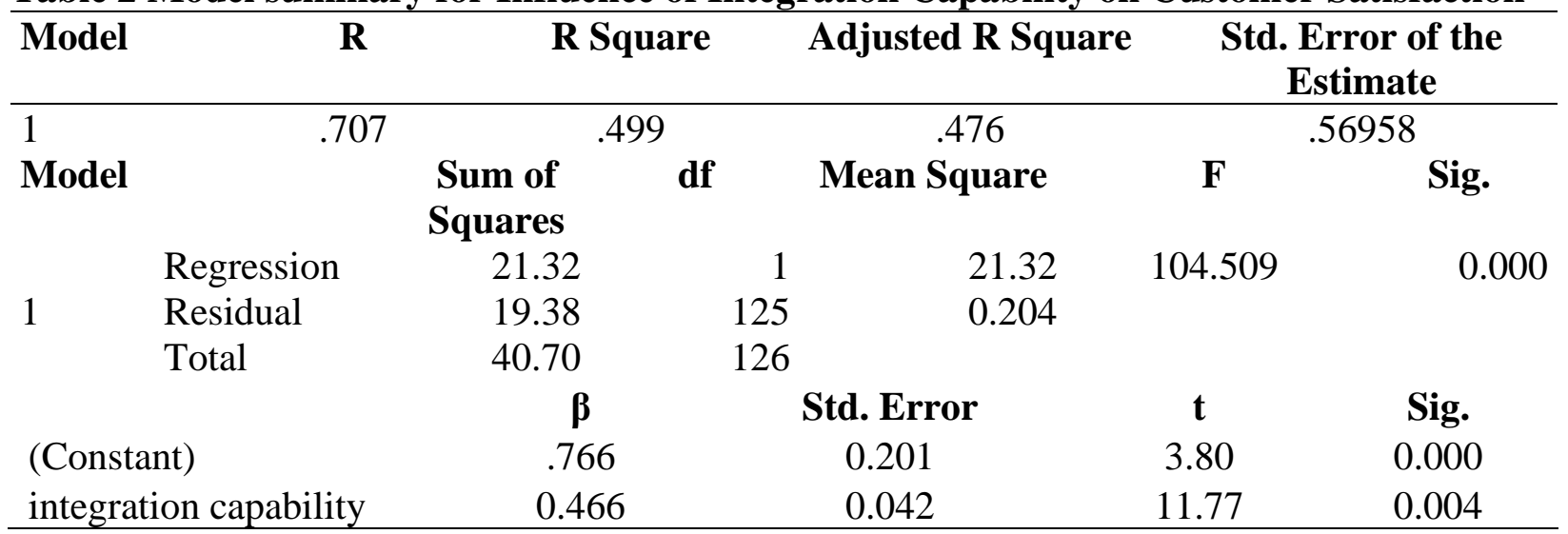

The results in table 2 presented the fitness of model of regression model used in explaining the influence of integration capability on customer satisfaction. Integration capability was found to be satisfactory variable in explaining customer satisfaction. This was supported by coefficient of determination also known as the $\mathrm{R}$ square of $49.9 \%$. This meant that integration capability explains $49.9 \%$ of the variations in customer satisfaction. The results further meant that the model applied to link the relationship of the variables was satisfactory. The outcomes of ANOVA showed that the final model was statistically significant. This was confirmed by the F statistic of 104.59 and 
International Journal of Business Management, Entrepreneurship and Innovation, Volume 3, Issue 3, 2021, PP 1-17, ISSN 2707-8027

IBMED

the recorded $\mathrm{p}$ value (0.000) that was smaller than the 0.05 significance level. Regression of coefficients results revealed that change in integration capability has a positive and significant influence on customer satisfaction $(\beta=0.466, \mathrm{p}=0.001)$. This means that a unit increase in integration capability would lead to an improvement in customer satisfaction by 0.466 units. The results agree with that of Pedron, Picoto, Colaco, and Araújo (2018) who found out that integration capabilities enabled better customer relationship management which in turn generated innovation.

\subsection{Influence of Innovation Capability on customer satisfaction}

The study aimed at assessing the influence of Innovation Capability on customer satisfaction. Correlation analysis was conducted to find out the link that exist between Innovation Capability and customer satisfaction. The findings showed that there was a positive and significant relationship between Innovation Capability and customer satisfaction $(r=715, p=0.001)$. This implies more Innovation Capability would lead to more customer satisfaction. The findings support that of Peace and Sylva (2017) who found that the dimensions of service innovation used in four star hotels were effective in service delivery and service outcome which proved as an effective marketing tool satisfying many customers.

Table 3 Regression Model summary for Influence of Innovation Capability on customer satisfaction

\begin{tabular}{|c|c|c|c|c|c|}
\hline \multirow[t]{2}{*}{ Model } & $\mathbf{R}$ & R Square & Adjusted R Square & \multicolumn{2}{|c|}{$\begin{array}{l}\text { Std. Error of the } \\
\text { Estimate }\end{array}$} \\
\hline & .715 & .511 & .502 & & \\
\hline \multirow[t]{2}{*}{ Model } & & $\begin{array}{l}\text { Sum of } \\
\text { Squares }\end{array}$ & $\begin{array}{l}\text { Mean } \\
\text { Square }\end{array}$ & $\mathbf{F}$ & Sig. \\
\hline & Regression & 33.65 & 33.65 & 119.98 & 0.000 \\
\hline \multirow[t]{3}{*}{1} & Residual & 25.19 & 0.265 & & \\
\hline & Total & 35.12 & 126 & & \\
\hline & & $\boldsymbol{\beta}$ & Std. Error & $\mathbf{t}$ & Sig. \\
\hline \multicolumn{2}{|c|}{ (Constant) } & 1.673 & 0.189 & 7.95 & 0.000 \\
\hline \multicolumn{2}{|c|}{ Innovation Capability } & 0.486 & 0.078 & 6.50 & 0.005 \\
\hline
\end{tabular}

The results in table 3 presented the fitness of model of regression model used in explaining the influence of Innovation Capability on customer satisfaction. Innovation Capability was found to be satisfactory variable in explaining customer satisfaction. This was supported by coefficient of determination of $51.1 \%$. This meant that Innovation Capability explain $51.1 \%$ of the variations in customer satisfaction. The results further meant that the model applied to link the relationship of the variables was satisfactory. The outcomes of ANOVA showed that the final model was statistically significant. This was confirmed by the F statistic of 119.98 and the recorded $p$ value (0.000) that was smaller than 0.05. Regression of coefficients results revealed that Innovation Capability has a positive and significant influence on customer satisfaction $(\beta=0.486, p=0.005)$. This means that a unit increase in Innovation Capability would lead to a rise in customer satisfaction by 0.486 units. This agrees with Kiey and Bayoh (2017) who found out a positive and a significant relationship between innovation and customer retention. Service innovation was found to be a chief determinant of customer satisfaction. 
International Journal of Business Management, Entrepreneurship and Innovation, Volume 3, Issue 3, 2021, PP 1-17, ISSN 2707-8027

IBMED

\subsection{Influence of Strategic Alliances on Customer Satisfaction}

The study aimed at assessing the influence of strategic alliances on customer satisfaction. Correlation analysis was conducted to find out the relationship between strategic alliances and customer satisfaction.

Table 4 Model summary for Influence of strategic alliances on customer satisfaction

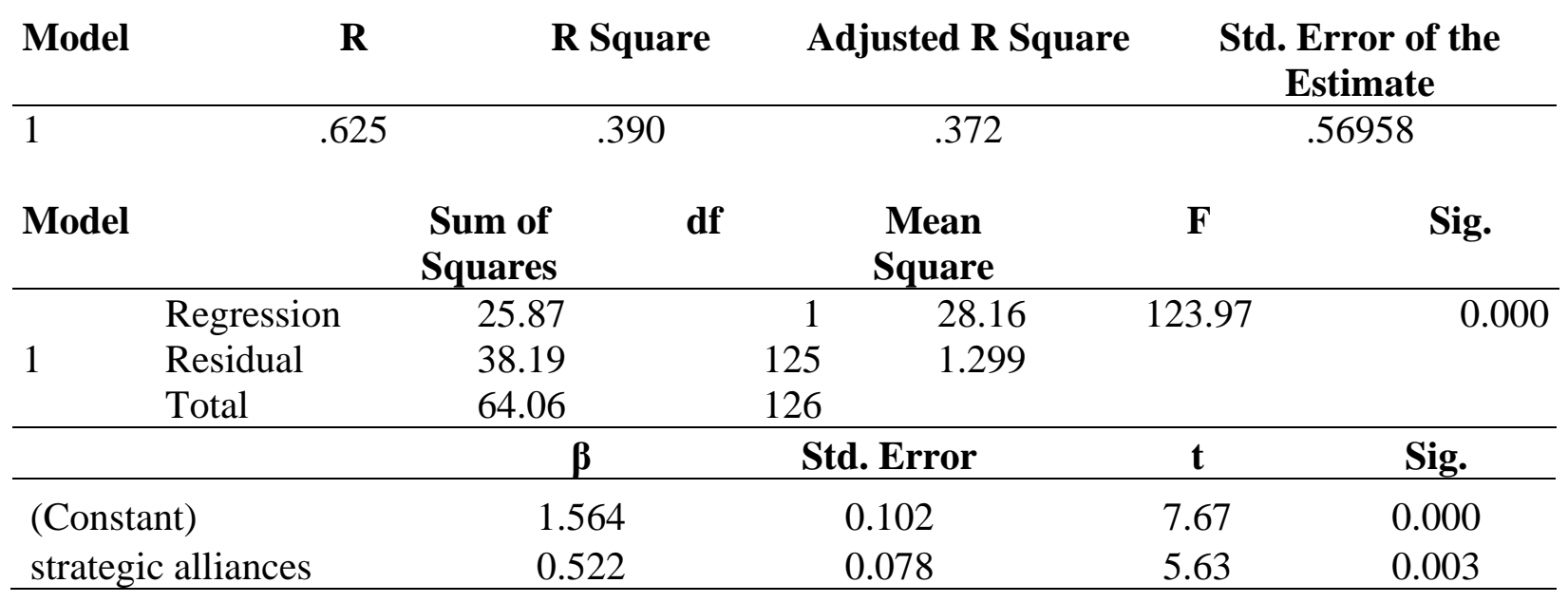

The results in table 4 presented the fitness of model of regression model used in explaining the influence of strategic alliances on customer satisfaction. Strategic alliances was found to be satisfactory variable in explaining customer satisfaction. This was supported by coefficient of determination of $61.5 \%$. This meant that strategic alliances explain $61.5 \%$ of the variations in customer satisfaction. The results further meant that the model applied to link the relationship of the variables was satisfactory. The outcomes of ANOVA showed that the final model was statistically significant. This was confirmed by the F statistic of 123.97 and the recorded $p$ value $(0.000)$ that was smaller than 0.05 . Regression of coefficients results revealed that strategic alliances has a positive and significant influence on customer satisfaction $(\beta=0.522, p=0.003)$. This means that a unit increase in strategic alliances would lead to an increase in customer satisfaction by 0.522 units. The results agree with that of Wandia and Ismail (2019) who found a positive influence of strategic alliances on the performance of commercial banks in Kenya.

\subsection{Conclusions and Recommendations}

\subsection{Conclusions}

Based on the findings above the study concluded that Learning capability significantly affect customer satisfaction in Nairobi city county, investment firms. The study also concluded that encouraging participative decision making between among all staff leads to improved customer satisfaction. It was also concluded that having open forums during which staff share ideas is important as it enhances customer satisfaction. Moreover, it was concluded that having both the senior and subordinate staff involved in setting organizational goals leads to customer satisfaction. It was further concluded that having all stakeholders are invited on board to take part in strategic planning improves customer loyalty. Based on the findings above, it was concluded that integration capability positively and significantly affects customer satisfaction in Nairobi city county, investment firms. Furthermore, it was concluded that when the management is aggressive in 
International Journal of Business Management, Entrepreneurship and Innovation, Volume 3, Issue 3, 2021, PP 1-17, ISSN 2707-8027

IBMED

revision of firm goals and activities, it increases customer satisfaction. It was further concluded that integrating different functions to reach a wider market enhances customer satisfaction.

The study concluded that innovation capability and strategic alliances positively and significantly affect customer satisfaction in Nairobi city county, investment firms. Additionally, the researcher concluded that adjusting firm products and services to rhyme with customer demands leads to improved customer satisfaction. Based on the study findings, it was also concluded that market innovation, developing products and services for various market segments and penetrating into new markets to increase market share enhances customer loyalty. Moreover, it was concluded that having a friendly service delivery is a prerequisite for customer satisfaction. The study concluded that strategic alliances positively and significantly affect customer satisfaction in Nairobi city county, investment firms. The researcher further concluded that entering into strategic partnership for knowledge sharing, risk sharing and sharing of expertise leads to improved customer satisfaction.

\subsection{Recommendations}

Based on the study findings, it was recommended that Investment firm's management should encourage participative decision making between among all staff to enhance customer loyalty. Firms should implement open forums during which staff share ideas to enhance customer satisfaction. Based on the study findings, it was recommended that management should be aggressive in revision of firm goals and activities to increase customer satisfaction. It was also recommended that firms should be keen in identifying the diversification activities that may be adopted and should be aggressive in seizing any market opportunities before competitors. Based on the study findings, it was recommended that firms should be aggressively involved in market innovation to enhance service delivery and customer loyalty. It was also recommended that firms should endeavor to penetrate into new markets thus increasing the market share and customer satisfaction. It was recommended that firms should enter into strategic partnerships for knowledge sharing, risk sharing and sharing of expertise which leads to improved customer satisfaction. Firms should also enter into strategic partnership for easier resource outsourcing and entered into strategic partnership for easier resource outsourcing, thus improving service delivery and subsequent customer satisfaction.

\section{References}

Akgün, A. E., Keskin, H., Byrne, J. C., \& Aren, S. (2007). Emotional and learning capability and their impact on product innovativeness and firm performance. Technovation, 27(9), 501 513.

Ambrosini, V., \& Bowman, C. (2009). What are dynamic capabilities and are they a useful

Anderson, E.W, Fornell C. \& Lehmann.D.R. (1994), Customer satisfaction, market share and profitability, journal of marketing (58)

Arend, R. J. (2014). Entrepreneurship and dynamic capabilities: how firm age and size affect the 'capability enhancement-SME performance'relationship. Small Business Economics, 42(1), 33-57.

Barney, J. (1991). Firm resources and sustained competitive advantage. Journal of management, 17(1), 99-120.

Chaharbaghi, K., \& Lynch, R. (1999). Sustainable competitive advantage: towards a dynamic resource-based strategy. Management Decision. 
International Journal of Business Management, Entrepreneurship and Innovation, Volume 3, Issue 3, 2021, PP 1-17, ISSN 2707-8027

E-

Coates, T. T., \& McDermott, C. M. (2002). An exploratory analysis of new competencies: a resource based view perspective. Journal of Operations Management, 20(5), 435-450.

Diaw, B., \& Asare, G. (2018). Effect of Innovation On Customer Satisfaction And Customer Retention In The Telecommunication Industry In Ghana: Customers 'perspectives. European Journal of Research and Reflection in Management Sciences Vol, 6(4).

Fornell, C., Mithas, S., Morgeson, F.V. III, \& Krishnan, M.S. (2006). Customer Satisfaction and Stock Prices: High Returns, Low Risk. Journal of Marketing, 70, 3-14.

Gichuru, P. W. (2011). Customer Satisfaction Survey: A Case of the Jubilee Insurance Company of Kenya Limited (Doctoral dissertation, University of Nairobi).

Hailekiros, G. S., \& Renyong, H. (2016). The effect of organizational learning capability on firm performance: Mediated by technological innovation capability. European Journal of Business Management, 8(30), 87-95.

Hou, J. J., \& Chien, Y. T. (2010). The effect of market knowledge management competence on business performance: a dynamic capabilities perspective. International Journal of Electronic Business Management, 8(2), 96.

Kanyuru, M. M. (2010). The relationship between capital structure and financial performance of firms listed at the Nairobi Stock Exchange. Unpublished MBA Research Project, University of Nairobi.

Karimi, D. G. (2013). Relationship between Investment Portfolio Choice and Profitability of Investment Companies Listed in the Nairobi Securities Exchange. Unpublished MBA Project.

Kiey, D. A, \& Bayoh, A. T (2017). Innovation and Customer Retention in the Ghanaian Telecommunication Industry. International journal of innovation, International Journal of Innovation (IJI Journal), 5(2), 171-183.

Kilimo, N. C., \& Finance, I. (2012). The effects of Strategic Alliances on the Financial Performance of Commercial Banks in Kenya. Jomo Kenyatta University of Agriculture technology.

Kimani, E. (2014). Effects of strategic alliance on competitive advantage in Airtel Kenya limited. Unpublished MBA project.

Kuria, M. M. (2015). Dynamic capability and competitiveness of Safaricom Limited in Kenya (Doctoral dissertation, Doctoral dissertation. University of Nairobi).

Lango, B. (2014). Factors Influencing Fire Service Delivery: A Case of Fire Stations in Kiambu County, Kenya (Doctoral dissertation, University Of Nairobi).

Management.Strategic Management Journal, 18, pp. 509-533.

Mugo, J. G. (2012). The effect of financial innovation on the growth of micro-finance Institutions in Kenya. Unpublished MBA project, University of Nairobi, Kenya.

Mugo, J. G. (2012). The effect of financial innovation on the growth of micro-finance Institutions in Kenya. Unpublished MBA project, University of Nairobi, Kenya.

Nguyen, H., Nguyen, H., Nguyen, N., \& Phan, A. (2018). Determinants of Customer Satisfaction and Loyalty in Vietnamese Life-Insurance Setting. Sustainability, 10(4), 1151.

NSE (2018). Nairobi Security Exchange Report. Retrieved from https://www.nse.co.ke/inverstorrelations/financial-reports-and-results/category/46-nse-annual-reports.html

Onağ, A. O., Tepeci, M., \& Başalp, A. A. (2014). Organizational learning capability and its impact on firm innovativeness. Procedia-Social and Behavioral Sciences, 150, 708-717.

Onyando, N. T. (2018). Dynamic capabilities, leadership behaviour and performance of manufacturing firms in Nairobi, Kenya (Doctoral dissertation, Moi University). 
International Journal of Business Management, Entrepreneurship and Innovation, Volume 3, Issue 3, 2021, PP 1-17, ISSN 2707-8027

IBMED

Peace, I. \& Sylva E, K. (2017). Service Innovativeness and Customer Satisfaction of Four Star Hotels in Rivers State. Masters of Marketing, University of Port Harcourt, Nigeria.

Pedron, C. D., Picoto, W. N., Colaco, M., \& Araújo, C. C. (2018). CRM System: the Role of Dynamic Capabilities in creating Innovation Capability. BBR. Brazilian Business Review, 15(5), 494-511.

Robson, C. (2002). Real world research: A resource for social scientists and practitionerresearchers. Vol. 2. Oxford: Blackwell.

Santonja, A., Sánchez-Muñoz, A., Lluch, A., Chica-Parrado, M. R., Albanell, J., Chacón, J. I., ... \& Alba, E. (2018). Triple negative breast cancer subtypes and pathologic complete response rate to neoadjuvant chemotherapy. Oncotarget, 9(41), 26406.

Scholes, K., \& Johnson, G. (Eds.). (2001). Exploring public sector strategy. Pearson Education.

Teece, D. J.: Pisano, G. \&Shuen, A. (1997). Dynamic Capabilities and Strategic

Teece, D.J. (2007). "Explicating dynamic capabilities: the nature and micro foundations of sustainable enterprise performance", Strategic Management Journal, 28, (13), 1319- 1350.

Tongco, M. D. C. (2007). Purposive sampling as a tool for informant selection. Ethnobotany Research and applications, 5, 147-158.

Tongco, M. D. C. (2007). Purposive sampling as a tool for informant selection. Ethnobotany Research and applications, 5, 147-158.

Mwangi, D. W. (2014). Effect of Strategic Alliances on the Growth of Kenya Commercial Bank Group. MBA project, University of Nairobi, Kenya.

Turrel, O \& Serenko A, (2006). Satisfaction with mobile services in Canada: An empirical investigation, Telecommunication policy.

Wandia, W. M., \& Ismail, N. O. O. R. (2019). Effects of Strategic Alliances on Performance of Commercial Banks in Kenya: A Case of Kenya Commercial Bank Limited. International Journal of Business Management and Finance, 2(1).

Wernerfelt, B. (1995). The resource-based view of the firm: Ten years after. Strategic management journal, 16(3), 171-174.

Wogwu, V. E., \& Hamilton, D. I. (2018). Reconfiguration Capability and Competitive Advantage: A Study of Port Harcourt Public Health Sector. Management, 8(2), 47-53.

Zahra, S. A., \& George, G. (2002). Absorptive capacity: A review, reconceptualization, and extension. Academy of management review, 27(2), 185-203.

This is an open-access article published and distributed under the terms and conditions of

the cc) Creative Commons Attribution 4.0 International License of United States unless otherwise stated. Access, citation and distribution of this article is allowed with full recognition of the authors and the source. Copyright, content ownership and liability for content herein remain with the authors. 